\title{
PELATIHAN ASPEK MARKETING MIX UNTUK USAHA MIKRO KECIL MENENGAH RUMARISA SEGAR JELLY DI KOTA JAMBI
}

\author{
${ }^{1 *}$ Feny Tialonawarmi, ${ }^{2}$ Fredy Olimsar \\ Fakultas Ekonomi dan Bisnis Universitas Jambi, Jambi, Indonesia \\ Email : ${ }^{*}$ fenytialona@unja.ac.id
}

Manuskrip: Desember -2021; Ditinjau: Januari -2022; Diterima: Januari -2022; Online: Januari-2022; Diterbitkan: Januari-2022

\begin{abstract}
ABSTRAK
Kegiatan pengabdian ini bertujuan untuk memberikan edukasi dalam bentuk pelatihan kepada pelaku usaha mikro kecil menengah Rumarisa Segarjelly yang berada di rumah pribadi daerah Kelurahan Kenali Besar Kecamatan Alam Barajo Kota Jambi dalam mengembangkan usahanya, sehingga dapat memudahkan untuk memahami kebutuhan dan keinginan konsumen. Selain itu, adapun tujuan umum yang dicapai adalah untuk meningkatkan pengetahuan dan pemahaman mengenai aspek marketing mix yang dapat dikembangkan sebagai dasar untuk melayani konsumen melalui proses manajemen marketing yang baik. Target dalam pengabdian ini pelaku usaha mikro kecil menengah dapat mengembangkan bisnis Rumarisa Segarjelly dengan menerapkan aspek marketing mix yang baik sehingga timbulnya kepuasan para konsumen
\end{abstract}

\section{Kata Kunci: Marketing Mix, Product, Promotion, Price, Place}

\section{PENDAHULUAN}

Usaha mikro kecil menengah (UMKM) merupakan salah satu sektor ekonomi yang berkembang di Indonesia. Sektor ini banyak diminati dan dijalankan kan oleh pelaku usaha dikarenakan mudah dikelola dan tidam membutuhkan anggaran biaya yang terlalu besar. Di Kota Jambi masih sedikit yang menjalankan usaha dogan jelly (kelapa muda yang dibuat menjadi jelly). Saat ini ada salah satu pelaku usaha yang sedang menjalankan bisnis dogan jelly ini yaitu "Rumarisa Segar Jelly". Rumarisa Segar Jelly ini termasuk bisnis yang masih baru berjalan sehingga belum banyak pengetahuan ataupun pengalaman di bidang marketing mix.

Dalam manajemen pemasaran terdapat beberapa bauran pemasaran atau yang sering disebut marketing mix. Marketing mix merupakan strategi yang digunakan pada kegiatan-kegiatan marketing, dimana dikombinasikan secara maksimal sehingga dapat hasil yang paling memuaskan. Oleh karena itu pada situasi ini ditujukan kepada pelaku usaha mikro kecil menengah Rumarisa Segar Jelly dapat menerapkan marketing mix yang baik, agar menghasilkan hasil yang memuaskan dan tujuan dapat tercapai secara efektif dan efisien. 
Pelatihan yang akan diberikan kepada pelaku usaha mikro kecil menengah Rumarisa Segar Jelly yaitu berupa penerapan bauran pemasaran yang terdiri dari 4P, yaitu yaitu product (produk), price (harga), place (tempat), dan promotion (promosi). Adapun pengertian dari masing-masing bauran pemasaran tersebut adalah sebagai berikut:

1. Product

Produk merupakan sesuatu yang ditawarkan pada pasaran agar dapat diperjualbelikan, dikonsumsi dan digunakan untuk memenuhi kebutuhan ataupun keinginan para konsumen.

2. Price

Harga merupakan nilai yang dapat digunakan untuk menjadi alat tukar pembeli kepada penjual dengan tujuan untuk mendapatkan manfaat, mengkonsumsi serta menggunakan produk atau jasa yang nilainya telah ditentukan oleh penjual, selain itu dapat juga terjadinya tawar menawar oleh pembeli.

3. Place

Tempat dapat diasosiasikan sebagai saluran pendistribusian yang ditujukan untuk mencapai target konsumen. Adapun aspek distribusi ini berupa lokasi, pergudanganan, transportasi dan lainnya.

4. Promotion

Promosi merupakan cara penjual untuk mendapatkan perhatian serta membujuk para pelanggan untuk membeli produk.

Berdasarkan penjelasan analisis situasi yang telah dijabarkan, dapat disimpulkan bahwa untuk mengembangkan bisnis pada pelaku usaha yang baru berjalan perlu diterapkan strategi pada kegiatan-kegiatan pemasaran, strategi tersebut dapat diterapkan melalui bauran pemasaran untuk pelaku usaha mikro kecil menengah Rumarisa Segar Jelly dimana usaha ini termasuk masih dalam kategori baru berjalan, sehingga pelaku usaha rumarisa segar jelly belum terlalu memahami dan mendalami bagaimana cara usaha yang dijalankan bisa memenuhi kebutuhan dan keinginan konsumen serta bisa terjual dan sampai ke tangan konsumen kemudian di sukai dan di kenal konsumen luas. Artinya usaha mikro kecil menengah ini masih minim akan pengetahuan dan pengalaman di bidang marketing. Maka, untuk menghadapi permasalahan yang timbul perlu di berikan pemahaman akan aspek marketing mix.

\section{METODE PELAKSANAAN KEGIATAN}

Metode pelaksanaan yang akan dilaksanakan dalam kegiatan ini berupa menyelesaikan masalah seperti hal mendalami pengetahuan dan pemahaman 
mengenai pemasaran seperti aspek marketing mix yang perlu dijalankan dengan baik agar tujuan pelaku usaha Rumarisa Segar Jelly dapat tercapai secara efektif dan efisien.

Untuk menghadapi permasalahan ini di fokuskan pada kegiatan pelatihan yaitu melakukan pelatihan aspek marketing mix seperti memberikan materi tentang produk yang diperjualkan harus memiliki kualitas yang baik serta produk pun harus beragam agar lebih banyak menarik perhatian pembeli sehingga adanya daya tarik konsumen untuk membeli dan adanya kepuasan para pelanggan. Selain memperhatikan kualitas produk harga juga perlu untuk diperhatikan dimulai dari biaya bahan baku, biaya tenaga kerja. Selanjutnya untuk tahap promosi harus ditingkatkan kegiatan promosinya agar lebih dikenal oleh masyarakat luas serta banyak peminat untuk membelinya dan disukai oleh pelanggan dan bagaimana cara terbaik untuk mendistribusikan produk sesuai dengan kebutuhan dan keinginan konsumen.

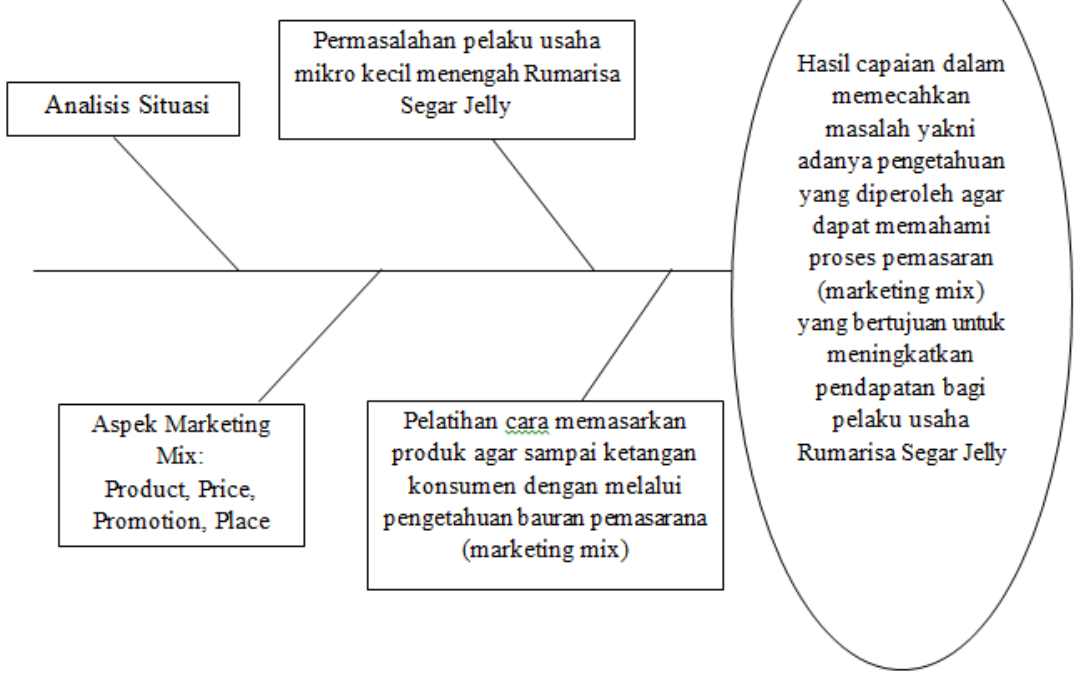

Gambar 1. Alur kegiatan dalam kegiatan pengabdian ini

\section{HASIL DAN PEMBAHASAN}

Pelaksanaan pelatihan aspek marketing mix kepada usaha mikro kecil menengah rumarisa segar jelly di Jln. Walisongo Rt. 03 Kel. Kenali Besar Kec. Alam Barajo Kota Jambi. Bentuk pelatihan yang dilakukan yaitu dengan pemberian materi kepada owner dan para pekerja di rumarisa segar jelly yang dilaksanakan satu hari pada tanggal 10 Oktober 2021 di kediaman owner rumarisa segar jelly, dimana merupakan temopat tinggalnya sekaligus tempat usaha mikro kecil menengah ini di bukanya. 


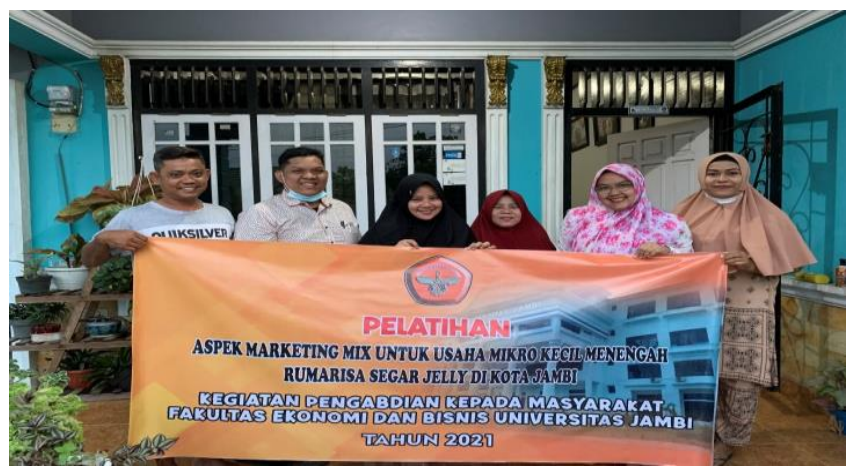

Gambar 2. Pelaksanaan Kegiatan Aspek Marketing Mix

Dalam kegiatan ini owner dan pekerja yang ikut membatu menjalankan usaha mikro kecil menengah dapat mengetahui bagaimana cara memasarkan produk yang mereka hasilkan agar terjual dan dikenal di pasaran. Pemasaran harus menjadi suatu konsep bisnis strategis yang bisa memberikan kepuasan berkelanjutan bukan kepuasan sesaat - untuk tiga stakeholder utama yakni pelanggan, karyawan dan pemilik perusahan. (Kartajaya, 2002). Untuk keberlanjutan kegiatan pemasaran, maka perlu memperhatikan strategi - strategi dalam pemasaran yang di kemas dalam Marketing Mix sebagai berikut:

a. Strategi pengembangan produk

Pada kenyataannya owner mengalami kesulitan menghadapi persaingan dengan pesaing yang memproduksi barang yang sama. Saat ini ada pesaing yang sedang menjual produk serupa dikisaran tempat UMKM rumarisa segar jelly ini. Solusi yang di tawarkan adalah hadapi pesaing dengan rasional artinya, mengedepankan unsur berkompetisi secara sehat, selain itu juga tetap terus beroperasi dan memperhatikan kedudukan produk yang di promosikan. Produk yang ada terus diperbaiki mutunya dengan berinovasi sesuai perkembangan zaman. Yang lebih penting harus ada berbagai jenis rasa atau varian yang menjadi ide atau inovasi baru pada produk dogan jelly tersebut, agar selangkah lebih maju dari pesaing.

b. Strategi penentuan harga

Ketepatan dalam penentuan harga akan produk yang di hasilkan adalah tugas pemasar. Harga yang tinggi dengan keuntungan per unit yang tinggi belum tentu mewujudkan keuntungan yang diharapkan. Sebaliknya harga yang rendah diikuti volume penjualan yang tinggi dapat menghasilkan keuntungan yang besar. Oleh karena itu, harga untuk produk dogan jelly ini harus disesuaikan dengan mayoritas ekonomi penduduk sekitar dan juga modal yang digunakan serta pengeluaran yang dikeluarkan untuk menjadikan dogan jelly ini sebagai produk yang dapat dinikmati oleh konsumennya.

c. Strategi promosi

Strategi promosi dogan jelly ini dapat dilakukan dengan cara memberikan informasi akan manfaat konsumen mengkonsumsi dogan jelly ini. Jika suatu 
prosuk memiliki manfaat ataupun khasiatnya maka pelanggan akan tertarik untuk membeli produk dogan jelly tersebut. Selanjutnya bisa dengan cara membujuk konsumen untuk membeli dogan jelly tersebut melalui pengiklanan secara offline maupun online seperti media sosial instagram, facebook, whatsapp dan lainnya..

d. Strategi distribusi

Hal pertama yang perlu di pikirkan dalam menentukkan strategi pendistribusian adalah menentukkan pihak yang akan mendistribusikan barang, yaitu apakah diserahkan kepada pihak yang lain atau di distribusikan langsung ke konsumen. Apabila dilakukan oleh pihak lain yaitu kita bisa menggunakan jasa kurir untuk membantu mengantarkan produk yang dijualkan kepada konsumen tersebut. Jasa kurir yang bisa digunakan di kota Jambi ini seperti grab, gojek dan maxim

\section{KESIMPULAN}

Berdasarkan pembahasan kegiatan pengabdian masyarakat ini dapat disimpulkan; Owner telah memahami proses marketing mix dimulai dari produk, price, promosi, distribusi dan stategi-strategi yang telah diberikan akan diterapkannya untuk menghadapi pesaing dan meningkatkan nilai produk dogan jelly tersebut.

\section{DAFTAR PUSTAKA}

Buchari Alma, (2011), Manajemen Pemasaran dan Pemasaran Jasa, Cetakan Kesembelian, Alfabeth, Bandung.

ER, T., Listiawati, et al. (2021). The Effect Of Online Marketing And E-Service Quality On Purchase Decisions: An Emprirical Study On Online Shop. Turkish Journal of Physiotherapy and Rehabilitation, 32(3).

Erlangga, H. (2021). Effect Of Digital Marketing And Social Media On Purchase Intention Of Smes Food Products. Turkish Journal of Computer and Mathematics Education (TURCOMAT), 12(3), 3672-3678.

Haryadi, R. N., Rojali, A., \& Fauzan, M. (2021). Sosialisasi Penggunaan Online Shop berbasis Website di UMKM Cimanggis. Jurnal Pengabdian Masyarakat Madani (JPMM), 1(1), 10-16.

Hermawan Kartajaya. (2002), Hermawan Kartajaya On Marketing, Jakarta PT. Gramedia Pustaka Utama.

Kotler, P. \& Keller, K.L. (2012), Manajemen Pemasaran Jilid I Edisi ke 12. Jakarta: Erlangga.

Pertiwi, M. I., Yulianto, E., \& Sunarti. (2016). Pengaruh Bauran Pemasaran Terhadap Keputusan Pembelian (Survei pada Konsumen Baker's King Donuts \& Coffee di MX Mall Malang). Jurnal Administrasi Bisnis, 37(1), $179-186$.

Singh, M. (2012). Marketing Mix of 4P'S For Competitive Advantage. Journal Of Business and Management, 3(6), 41-44. 